\title{
ASSESSMENT OF THE LEARNING PROCESS RISKS AT HIGHER EDUCATIONAL INSTITUTIONS IN ACCORDANCE WITH THE DSTU ISO 31010: 2013 REQUIREMENTS
}

\section{ОЦННЮВАННЯ РИЗИКІВ ОСВІТНЬОГО ПРОЦЕСУ ЗВО ЗГІДНО 3 ВИМОГАМИ ДСТУ ISO 31010:2013}

\section{Ganna Khimicheva ${ }^{1}$ \\ Antonina Volivach ${ }^{2}$}

DOI: https://doi.org/10.30525/978-9934-588-15-0-61

Abstract. The object of the study is to improve the process of identification and assessment of higher education institutions risks according to the requirements of DSTU ISO 31010:2013. The subject of the study is to select and substantiate mechanisms and tools for the educational process risks assessment according to the requirements of DSTU ISO 31010:2013. The methodological basis of the research is a systematic approach to the study of the research object. Experimental studies have been conducted using peer-review methods in the real world of higher education institutions. The purpose of the study is to select and substantiate methods, principles and approaches to identify risks in the educational process of higher education institutions, in accordance with the requirements of DSTU ISO 31010:2013. This article presents the research results on the possibility and expediency of applying the DSTU ISO 31010:2013 "Risk Management. General Risk Assessment Methods" requirements to identify and analyze the potential risks of the educational process. A special four-step algorithm has been developed to evaluate the risks of the educational process, which allows assessing the risks of this process at all stages of its life cycle. The mechanism is based on a systematic approach, principles of general quality management (TQM),

\footnotetext{
${ }^{1}$ Doctor of Technical Sciences, Professor of the Department of Computer-Integrated Technologies and Measuring Technique, Kyiv National University of Technologies and Design, Ukraine ${ }^{2}$ Senior Lecturer of the Department of Computer-Integrated Technologies and Measuring Technique,

Kyiv National University of Technologies and Design, Ukraine
} 
risk management and requirements of the standard DSTU ISO 31010: 2013. For practical implementation of this algorithm, the paper provides methodological recommendations concerning the general risk assessment (identification, qualitative analysis and quantitative assessment). In particular, the requirements for the expert working group formation have been outlined; external and internal environment have been defined, without which there can be no educational process; material resources have been given; a tree of properties of qualitative specialist training has been built; the methods of risk identification have been substantiated and the following have been considered: "Brainstorming", "Delphi" method, "Hazardous Factors Analysis and Critical Control Points (HACCP)", and SWOT analysis; it has been found out that the choice of identification method depends on the educational process specifics and is the prerogative of higher education institution; the classification of the educational process risks in the form of a three-level structure, the essence of which is to establish relationships between the levels and to determine the factors of their impact; the expert method has identified six groups of major risks of educational process and provides single indicators for their evaluation; a qualitative and quantitative analysis of potential risks have been conducted using the mapping method and the possibility of risks and the level of their consequences have been determined; the most risky areas of the educational process have been identified, which requires special attention, development and implementation of actions to reduce them; an action plan for minimizing potential risks has been outlined. The prospects for further research are related to a more detailed study of the educational process risks, in particular the impact of their economic component on the higher education institutions activities.

\section{1. Ветуп}

Ринок праці все більше залежить від набутих професійних навичок спеціалістів, з однієї сторони та більш жорстких вимог роботодавців до випускників закладів вищої освіти з іншої. Національна економіка країн потребує підготовки висококваліфікованих фахівців. Проте, в сучасних умовах діяльність закладів вищої освіти (ЗВО), як і будь-якої організації (установи) пов'язана з ризиками.

Питаннями діяльності ЗВО, в тому числі й оцінюванням їх ризиків займалися ряд вітчизняних і закордонних науковців, а саме: Прой- 
дак Ю.С., Гаман П.І., Ревенко О.О., Должанський А.М., Донець О.М., Урецька Ю.І., Родіонова Н.Ф., Заярна І.Я., Альжанова Н.Ш. та інші.

Міжнародною організацією зі стандартизації для прогнозування та запобігання ризиків розроблена ціла серія стандартів ISO 31000. Дані стандарти є універсальним інструментом управління ризиками для прийняття рішень, формування стратегічних цілей спрямованих на зменшення ризиків та підвищення конкурентоспроможності будь-якої організації (установи), в тому числі і ЗВО.

Тому дослідження пов'язані з оцінюванням ризиків освітнього процесу ЗВО є своєчасними і актуальними.

Об'єктом дослідження є вдосконалення процесу ідентифікації та оцінки ризиків закладів вищої освіти за вимогами стандарту ДСТУ ISO 31010:2013.

Предметом дослідження $є$ вибір та обгрунтування механізмів й інструментів оцінювання ризиків освітнього процесу за вимогами стандарту ДСТУ ISO 31010:2013.

Методологічною основою досліджень є системний підхід до вивчення об'єкта досліджень. Експериментальні дослідження проводились за допомогою методів експертних оцінок в реальних умовах закладів вищої освіти.

Метою дослідження $є$ вибір і обгрунтування методів, принципів і підходів до ідентифікації ризиків освітнього процесу закладів вищої освіти, згідно з вимогами стандарту ДСТУ ISO 31010:2013.

Основне завдання даного дослідження полягає у побудові алгоритму оцінювання ризиків освітнього процесу ЗВО. Для цього в роботі було сформовано робочу групу експертів, визначено зовнішнє та внутрішнє середовище, яке обумовлює ризики освітньої діяльності. Зокрема побудовано дерево властивостей якісного фахівця, вибрано й обгрунтовано методи ідентифікації ризиків. За допомогою методу картографування проведено якісний та кількісний аналіз ризиків та запропоновано комплекс організаційно-технічних заходів по їх зменшенню.

\section{2. Результати експериментальних досліджень}

Одним із важливих етапів управління ризиками для організацій, підприємств, установ зокрема закладів вищої освіти $€$ їх оцінка. Згідно 3 [1;2] оцінка ризиків узагальнює процес ідентифікації, аналізу та їх 
подальше оцінювання. Проте, для вірогідного, об'єктивного й своєчасного виявлення ризиків будь-якого об'єкту, у нашому випадку освітнього процесу 3ВО, потрібно мати якісну інформацію, яка надавала б всебічне уявлення про фактори (чинники) їх виникнення, з метою їх мінімізації. Ефективним механізмом управління ризиками освітнього процесу $€$ застосування міжнародного стандарту ДСТУ ISO 31010:2013 «Керування ризиком. Методи загального оцінювання ризику». Даний стандарт є універсальним, передбачає логічні, науково обгрунтовані підходи щодо управління та загального оцінювання ризиків, допомагає приймати ефективні рішення в умовах невизначеності [3].

В ході досліджень для оцінювання впливу ризиків на освітній процес було розроблено спеціальний механізм (рис. 1), який дозволяє виявляти та корегувати ризики на усіх етапах життєвого циклу. Даний механізм складається з чотирьох етапів.

Розглянемо більш детально кожен з них. Так на першому етапі необхідно сформувати робочу групу. Основні вимоги до якої та алгоритм відбору експертів наведено у роботі [4], а перелік критеріїв в таблиці 1.

Таблиця 1

Перелік критеріїв відбору експертів

\begin{tabular}{|l|l|c|}
\hline \multicolumn{2}{|c|}{ Критерії відбору (К) } \\
\hline \multirow{2}{*}{ Відповідна кваліфікація } & Науковий ступінь & К1 \\
\cline { 2 - 3 } & Вчене звання & К2 \\
\hline Стаж роботи & К3 \\
\hline Наявність публікацій за напрямом оцінювання за останні 5-ть років & К4 \\
\hline Участь в експертних групах за об’єктом дослідження за останні 5-ть років & К5 \\
\hline
\end{tabular}

Перелічені критерії дають можливість оцінити та визначити компетентність потенційних учасників експертної групи.

Варто зазначити, що дана група є постійно діючою, від якості іiі роботи залежить повнота та вірогідність інформації стосовно впливу ризиків на освітній процес. Експертна група в ході роботи забезпечує консультації з питань виявлення ризиків та розроблення організаційно-технічних заходів щодо зменшення їх впливу на освітній процес.

На другому етапі, визначаються зовнішнє та внутрішнє оточення. У роботі [5] авторами запропоновано структурувати зовнішні фактори 
Ganna Khimicheva, Antonina Volivach

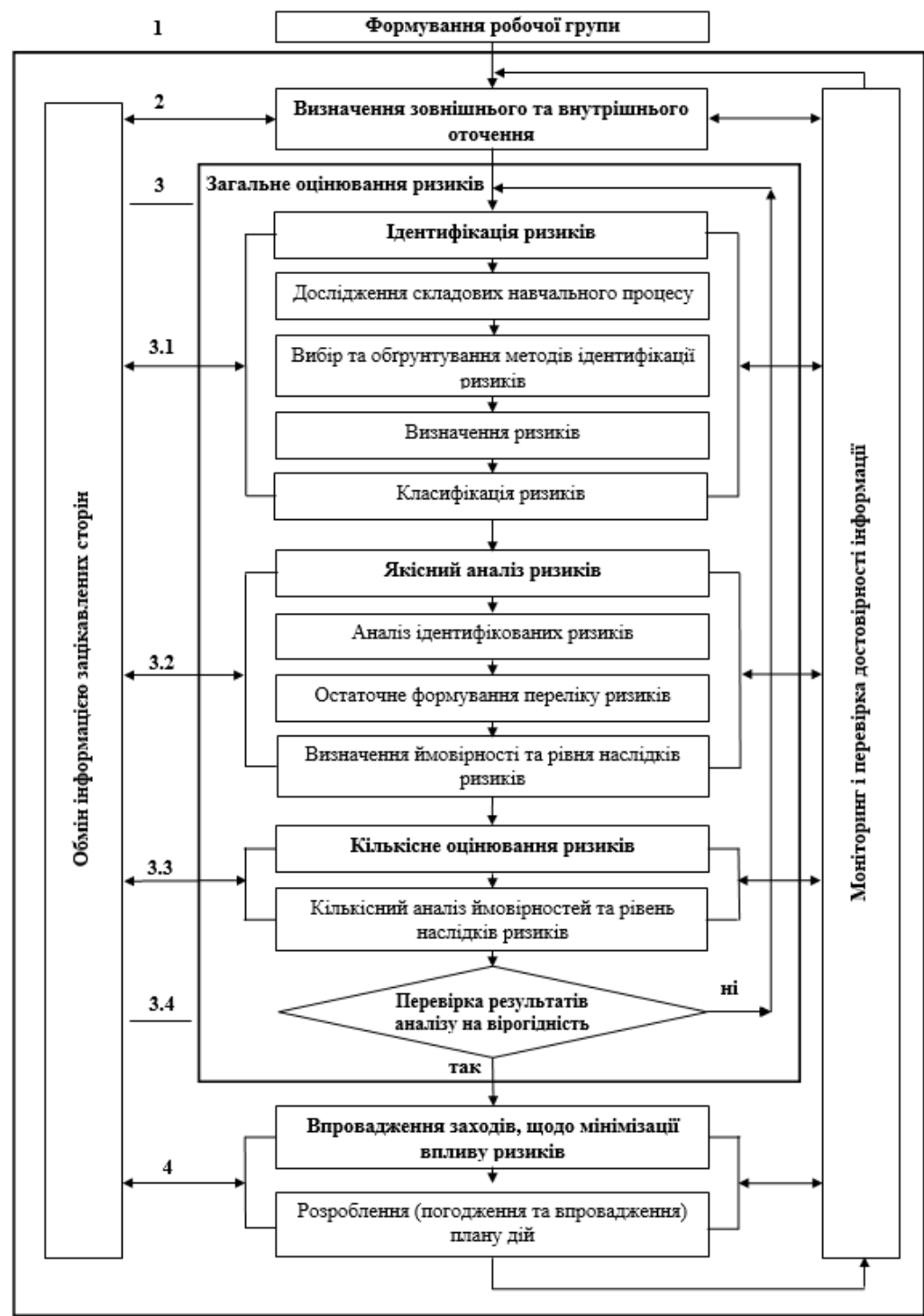

Рис. 1. Алгоритм оцінювання ризиків освітнього процесу 3 ВО згідно ДСТУ ISO 31010:2013 
впливу на два рівні: макросередовище та мікросередовище. До першого рівня (макросередовища) було віднесено такі фактори, як політичні, економічні та соціальні. В роботі [6] на прикладі Київського національного університету технологій та дизайну (КНУТД), за допомогою Pest-аналізу авторами було визначено найбільш суттєві фактори даного середовища.

Серед політичних факторів було виділено наступні: постійне удосконалення державної політики в освітній галузі; фінансування сфери освіти за залишковим принципом; політична ситуація в країні; інтеграція у європейський простір; зменшення кількості місць за бюджетним замовленням тощо.

Серед економічних факторів це: кризові явища та інфляція в економіці країни; посилення конкуренції на ринку надання освітніх послуг; впровадження рейтингового оцінювання 3ВО; потреба роботодавців у кваліфікованих фахівцях; регіональне розташування ЗВО.

Серед соціальних факторів: високий рівень безробіття та низький рівень матеріального забезпечення населення; міграція; недостатня кількість на ринку праці фахівців з інженерно-технічних спеціальностей та надлишок фахівців гуманітарних спеціальностей; низький рівень підготовки абітурієнтів.

Проте, слід зазначити, що для освітнього процесу найбільш вагомим $є$ другий рівень (мікросередовище), яке обумовлюється вимогами: споживачів освітніх послуг, роботодавців, умовами ринку праці, тобто суттєво впливає на конкурентоспроможність ЗВО в цілому. Дане середовище формується шляхом здобувачів вищої освіти, батьків, студентського самоврядування, науково-педагогічних та наукових працівників, вимог: випускових кафедр, деканатів, вченої ради та керівництва ЗВО, оточення без якого не може існувати освітній процес.

Для функціонування кожного з наведених вище середовищ потрібно мати відповідні матеріальні ресурси. Так наприклад, для освітнього процесу матеріальними ресурсами $є$ : кадрове забезпечення науково-педагогічних працівників, що враховує компетентність, вчене звання (професор, доцент), науковий ступінь (доктор наук, кандидат наук, доктор філософії, магістр), стаж роботи за профілем в зазначених межах (від 1 до 5, від 5 до 10, від 10 до 20, від 20 до 30, від 30 і більше років), наявність публікацій (підручники, навчальні посібники, монографіі), статті у наукометричних базах: Scopus, Web of science core Collection; рецен- 
зованих фахових виданнях (міжнародних і вітчизняних), навчально-методичне забезпечення освітньої програми (навчальні та робочі плани, навчальні та робочі програми дисциплін, конспекти лекцій, методичні розробки для лабораторних та практичних занять, пакет контрольних завдань 3 дисциплін, контроль знань (залік, екзамен, державний іспит / дипломна робота); матеріально-технічне забезпечення (лекційні аудиторії з інноваційним обладнанням, навчальні професійно-орієнтовані лабораторії з використанням інформаційних технологій і програмного забезпечення, комп'ютерні класи) та наукова діяльність, яка є інноваційною складовою освітнього процесу і включає: наукові дослідження в рамках держбюджетних робіт, госпдоговірні теми, ініціативні теми, договори про творчу співпрацю, конференції різних рівнів (міжнародні, всеукраїнські, інтернет-конференції, онлайн-конференції), круглі столи, стартапи, бізнес-інкубатори.

Дерево властивостей матеріальних ресурсів, яке враховує усі наведені вище складові, що впливають на ефективне проведення освітнього процесу і підготовку якісного фахівця наведено на рис. 2.

На наш погляд найбільш суттєвим є третій етап, який відповідає за загальне оцінювання ризиків (рис. 1). Він складається з чотирьох підетапів. Де 3.1 - ідентифікація ризиків; 3.2 - якісний аналіз ризиків; 3.3 - кількісне оцінювання ризиків та 3.4 - перевірка результатів аналізу на вірогідність.

Виконання усіх підетапів проводиться відповідно до пункту 4.3.4 стандарту [3]. Зокрема проведення робіт складається 3 визначення впливу негативних факторів на освітній процес, шляхом застосування методів структурованого аналізу.

Відомо, що базовим елементом ризик-менеджменту є ідентифікація ризиків (підетап 3.1). Як видно з рис. 1, основними процедурами ідентифікації є дослідження складових освітнього процесу; вибір та обгрунтування методів ідентифікації ризиків; визначення ризиків та їх класифікація. Виконання наведених вище процедур дозволяє виявити джерела ризику, ризикові дії, з'ясувати причини їх виникнення та оцінити наслідки негативного впливу на освітній процес.

Ідентифікація передбачає вивчення, збір та аналіз інформації щодо освітнього процесу і його складових, дослідження факторів впливу та визначення причин, джерел і характеру їх виникнення. Крім того, на даному підетапі особливу увагу потрібно приділяти процедурі вибору та обгрунту- 
вання методів, які дозволяють ідентифікувати ризики. Дана процедура безпосередньо впливає на вірогідність та якість результатів досліджень.

Стандарт [3] рекомендує для ідентифікації ризиків в різних галузях національної економіки застосовувати 15 основних методів. Проте, в ході досліджень було встановлено, що для освітнього процесу найбільш придатними є три методи: «Мозковий штурм», метод «Делфі» та «Аналіз небезпечних чинників і критичні точки контролю (НАССР)». Розглянемо більш детально кожен з них.

Практичний досвід доводить, що одним з найбільш розповсюджених методів ідентифікації $\epsilon$ метод «Мозковий штурм», який базується на висловлюваних ідеях усіх учасників експертної групи. Його суть полягає в тому, що в результаті групового обговорення та дискусій робочою групою визначаються чинники та ризики, з яких надалі складається перелік усіх можливих ризиків (які на думку експертів є важливими).

Даний метод доцільно використовувати для оцінювання ризиків на будь-якому етапі життєвого циклу освітнього процесу. Перевагою методу $є$ результативне координування, яке застосовується на початковому етапі і $є$ основою стимулювання експертів до обговорення та спрямування їх уваги на найбільш ризиковані аспекти освітнього процесу.

Метод «Мозковий штурм» може застосовуватись у двох видах формалізованому і неформалізованому. Формалізований - передбачає заздалегідь підготовлену стратегію обговорення, тобто є більш структурованим, за рахунок визначення мети і завдань проведення засідання та методів оцінювання, які будуть застосовуватись для об'єкта досліджень. Дані пункти потрібно визначити до початку роботи експертної групи. Неформалізований - залежить від ситуації тому є менш структурованим.

До переваг даного методу слід віднести: прийняття оригінальних рішень робочої групи, за рахунок творчого мислення. Це досягається шляхом залучення зацікавлених сторін, загального обміну інформацією, швидкого та легкого запровадження. Недоліками є великі витрати часу координатором на збір інформації (результатів думок експертів) та домінування ідей одних учасників групи над іншими, що надалі потребує розроблення окремих процедур для урівноваження результатів досліджень [3].

Наступний - метод «Делфі». В його основу покладено незалежні експертні оцінки. Суть даного методу полягає у незалежному опитуванні експертів робочої групи та перевірці узгодженості їх думок. На 


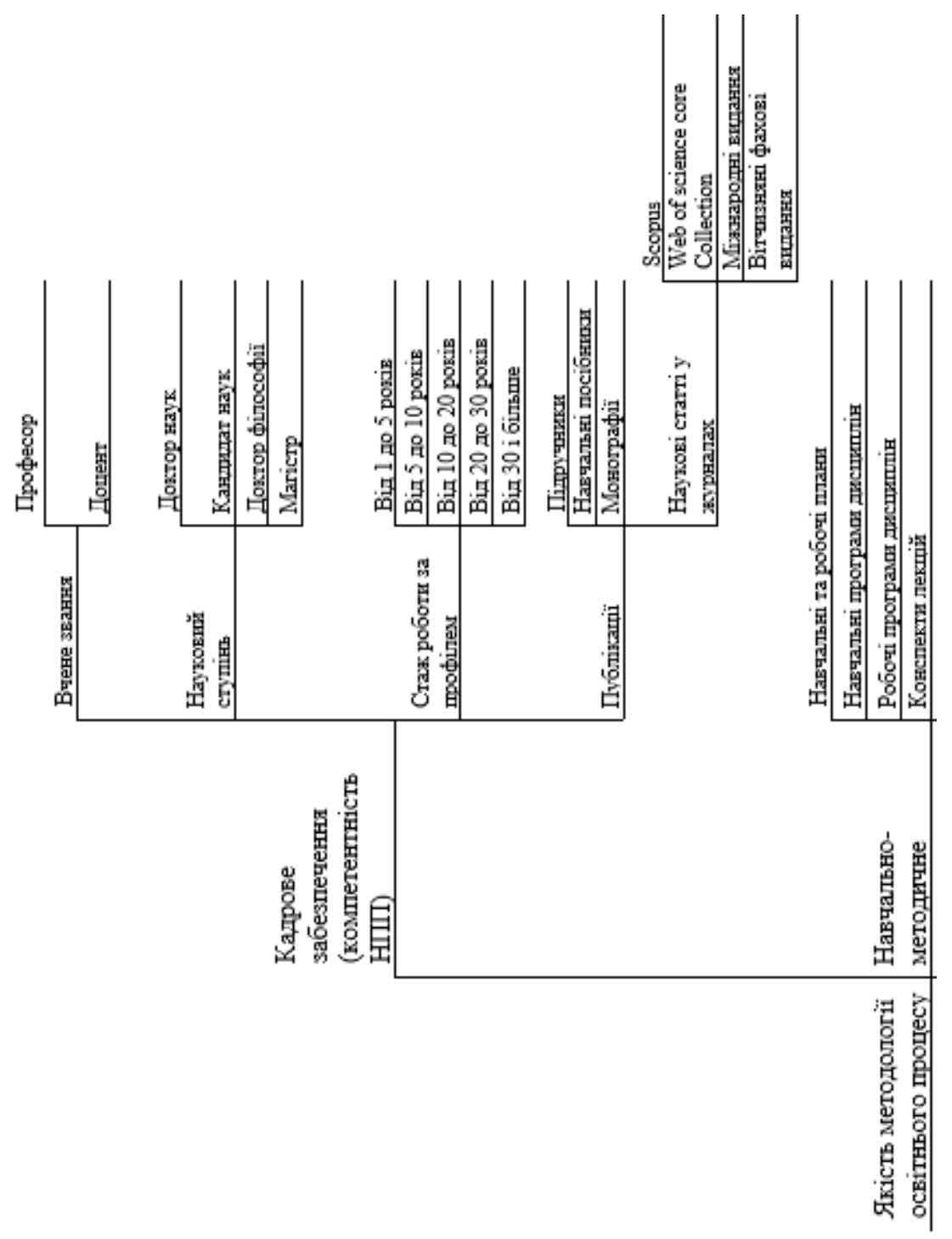




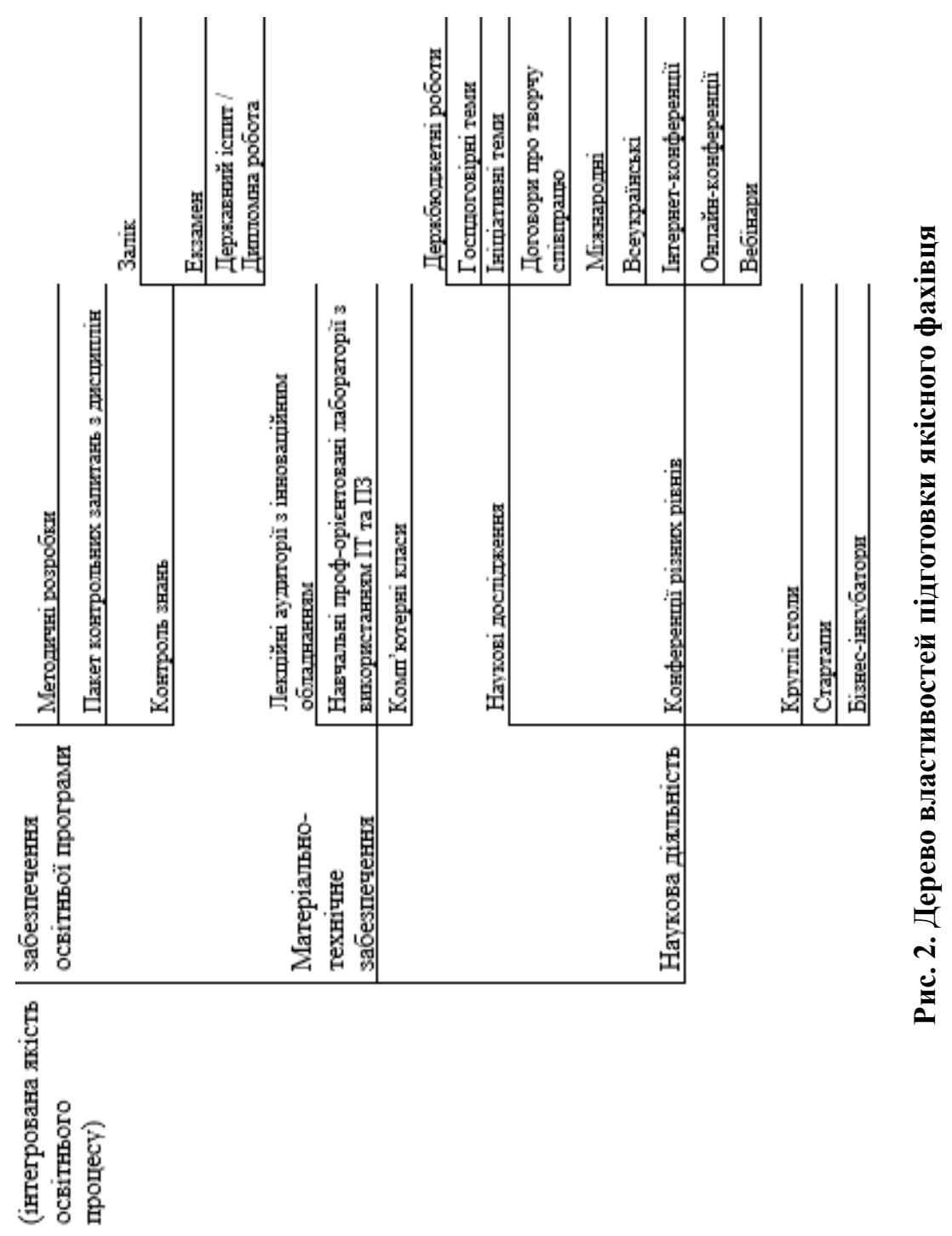


відміну від наведеного вище методу учасники групи не знайомі один 3 одним, висловлюють свої думки індивідуально й анонімно, заповнюючи для цього спеціально розроблені анкети, які надалі обробляються за допомогою статистичних методів. Результати анкетування повідомляються усім учасникам групи. Для підвищення вірогідності результатів оцінювання передбачено зворотний зв'язок, який відбувається шляхом проведення декількох турів анкетування. При цьому слід зазначити, що до експертів встановлюються певні вимоги, зокрема, вони повинні бути добре поінформованими про об'єкт дослідження (у нашому випадку освітній процес), в анкетах відповідати обгрунтовано, тобто проводити якісне і кількісне оцінювання ризиків.

Перевагами даного методу $є$ анонімність, відсутність впливу на думку окремого експерта, можливість роботи групи в різних місцях. Недоліком є досить великі затрати часу на його проведення.

Також, одним із запропонованих стандартом [3] методів є «Аналіз небезпечних чинників і критичні точки контролю (НАССР)», який на даний час найбільш широко застосовується в харчовій промисловості. Використання даного методу дозволяє ідентифікувати небезпечні чинники, запроваджувати засоби контролю, з метою запобігання їх впливу, що підвищує якість, надійність та безпечність надання будь-яких послуг, у тому числі й освітніх. Таким чином, метод спрямований на мінімізацію ризиків на усіх етапах життєвого циклу продукції (послуг). Для цього, згідно з вимогами стандарту [3] проводяться відповідні процедури, які документуються у вигляді протоколів, аналізу і плану роботи НАССР.

Перевагами даного методу є можливість отримувати задокументовані докази, які дозволяють надалі ідентифікувати та мінімізувати ризики, шляхом розробки контрольних листів, рекомендацій та організаційно-технічних заходів тощо. До недоліків слід віднести досить великі кадрові, економічні й часові затрати, у порівнянні з вище наведеними методами.

Проведені дослідження, які авторами викладені у роботі [7], довели, що крім наведених вище трьох методів для оцінювання ризиків освітньої діяльності доцільно застосовувати також широко відомий інструмент - SWOT-аналіз. Даний універсальний інструмент був апробований на прикладі КНУТД. Застосування даного інструменту дозволило оцінити зовнішнє та внутрішнє середовище, а також визначити можливості і загрози закладу, зокрема проведення ним освітнього процесу. 
Згідно з результатами дослідження для КНУТД було запропоновано чотири стратегії розвитку. При цьому однією з ефективних було визнано стратегію порівняння сильних сторін та можливостей, яка спрямована на інтеграцію ЗВО у європейський простір вищої освіти та отримання вищих позицій в національних і міжнародних рейтингових оцінюваннях. Дотримання даної стратегії забезпечує закладу вищої освіти випуск більш якісного спеціаліста та задовольняє потреби роботодавців, як в країні, так і за ії межами.

Крім того було встановлено, що особливу увагу потрібно приділяти стратегії слабких сторін і загроз. Оскільки дана стратегія повинна враховувати і передбачати потенційні ризики ЗВО.

Отже, як видно з вище наведеного, перелічені методи ідентифікації ризиків $є$ досить ефективними. Проте, під час їх вибору ЗВО потрібно враховувати специфіку свого освітнього процесу.

Наступною процедурою підетапу $3.1 \epsilon$ визначення ризиків, які доцільно проводити за типовою схемою наведеною в роботі [8]. Застосування даної схеми дозволяє визначити ризики освітньої діяльності ЗВО.

Завершальною процедурою ідентифікації ризиків $є$ їх класифікація, методика проведення якої наведена у роботі [5]. Дана методика передбачає побудову трирівневої структури. На першому рівні ризики поділяють на групи, на другому рівні - на підгрупи, на третьому рівні обгрунтовують фактори (чинники), що обумовлюють ризики освітнього процесу. Класифікація ризиків освітнього процесу за даною методикою наведена у роботі [5]. Такий підхід до побудови класифікації дозволяє встановити взаємозв'язки між рівнями та визначити їх фактори впливу.

Для якісного оцінювання ризиків застосовується підетап 3.2. Під час якого, згідно зі стандартом [3] визначаються ймовірність та рівень наслідків попередньо ідентифікованих ризиків. Даний підетап складається 3 трьох процедур: аналізу ідентифікованих ризиків, остаточного формування переліку ризиків й визначення ймовірності та рівня наслідків ризиків.

Перша процедура підетапу 3.2 - аналіз ідентифікованих ризиків передбачає поглиблене їх розуміння. Тобто дозволяє визначити причини і джерела ризиків, ймовірності виникнення та їх наслідки. Для цього потрібно мати якісні вхідні дані щодо загального оцінювання ризиків, на основі яких надалі можна приймати обгрунтовані рішення. Результати обробляються експертною групою за допомо- 
гою методів ранжування. Кінцевою метою даного підетапу є остаточне формування переліку ризиків, що $є$ наступною процедурою. За вимогами стандарту [3] для цього визначається характер і тип впливу за припущеннями, що відбуваються за конкретної події чи настають за конкретних обставин. Дана подія може викликати різний ступінь впливу та негативно впливати на складові освітнього процесу. Тому вона потребує аналізу якісної оцінки її наслідків.

Для визначення ймовірності та рівня наслідків ризиків щодо їх значущості використовуються наступна шкала - «незначний», «низький», «середній», «високий», «дуже високий».

В ході проведення експерименту для КНУТД, робочою групою було встановлено шість основних видів ризиків, які впливають на освітній процес. Повна характеристика цих ризиків наведена в роботі [7]. Це:

1) ризики проектування навчання;

2) ризики матеріально-технічної бази навчання;

3) ризики професорсько-викладацького складу;

4) ризики наукової діяльності;

5) ризики виховної роботи;

6) ризики випуску фахівців.

В подальшому ці ризики були структуровані, для кожного 3 них було визначено одиничні показники, наприклад для ризику недостатнього розвитку чи застарілого матеріально технічного забезпечення, одичними показниками $є$ : недостатнє фінансове забезпечення; недостатнє впровадження інформаційних та інноваційних технологій; відсутність обладнання з використанням інформаційних технологій; відсутність сучасних лабораторних установок тощо.

Отже, як видно з наведеного вище, одиничні показники дозволяють оцінювати підпроцеси, з яких складається освітній процес в цілому.

Схема ризиків освітнього процесу наведена на рис. 3 .

Для остаточного формування переліку ризиків, за допомогою експертних методів була сформована таблиця 2.

Проте, оскільки якісний аналіз не дає повного уявлення про рівень впливу ризиків та їх наслідки, доцільно, згідно стандарту [3] застосовувати кількісне оцінювання, підетап - 3.3 (рис. 1). Для цього в ході оцінювання експертною групою визначаються ймовірність та рівень наслідків ризиків. 


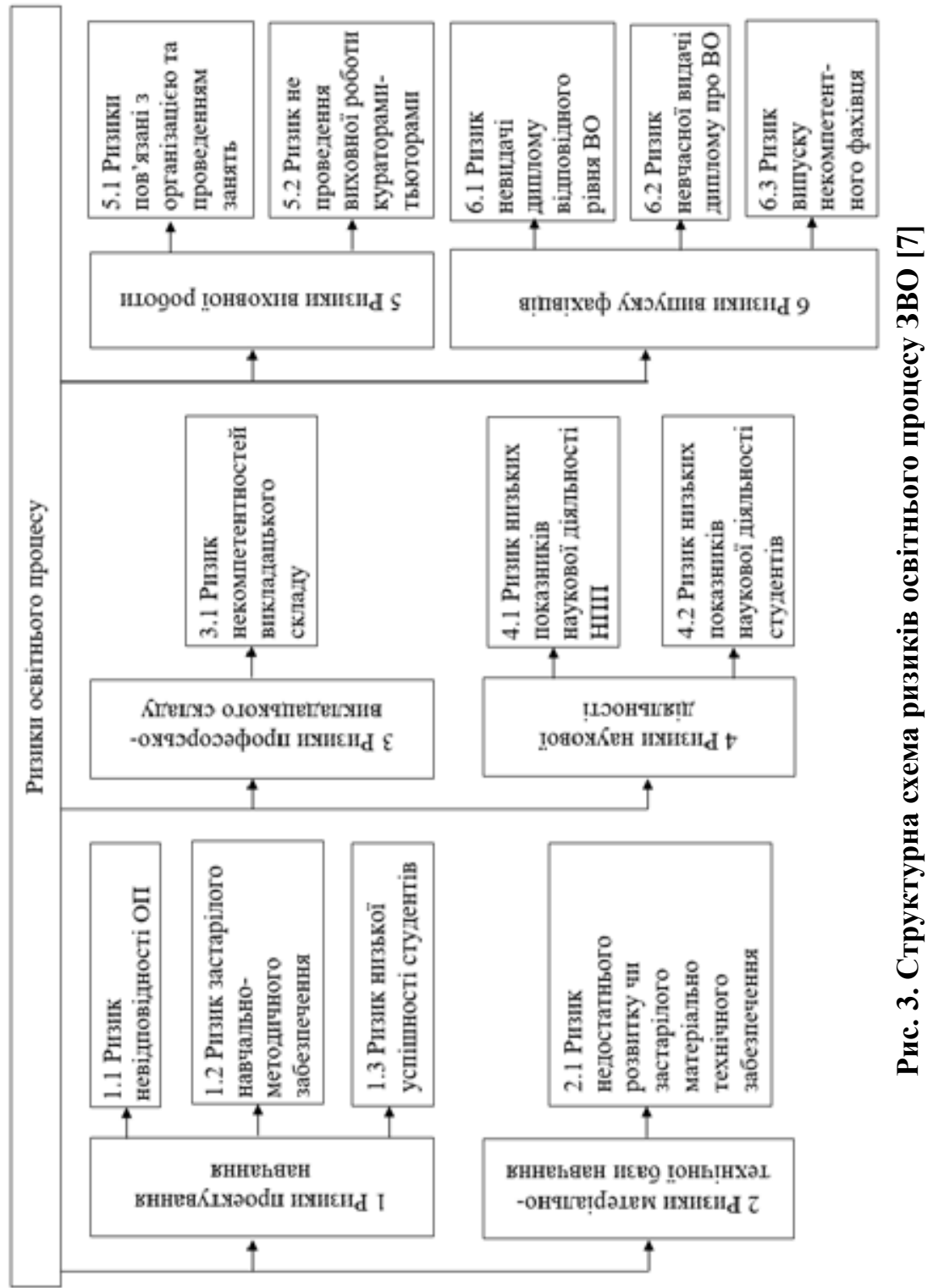


Таблиця 2

Ризики освітнього процесу

\begin{tabular}{|c|c|c|}
\hline $\begin{array}{l}\text { Інтегровані } \\
\text { показники }\end{array}$ & Одиничні показники & Наслідки ризиків \\
\hline 1 & 2 & 3 \\
\hline \multicolumn{3}{|c|}{ 1. Ризики проектування навчання } \\
\hline $\begin{array}{l}\text { 1.1. Ризик } \\
\text { невідповідності ОП }\end{array}$ & $\begin{array}{l}\text { ОП не відповідає системі } \\
\text { освітніх компонентів }\end{array}$ & $\begin{array}{l}\text { не буде отримано відповід- } \\
\text { них очікуваних результатів } \\
\text { навчання }\end{array}$ \\
\hline $\begin{array}{l}\text { 1.2. Ризик } \\
\text { застарілого } \\
\text { навчально- } \\
\text { методичного } \\
\text { забезпечення }\end{array}$ & $\begin{array}{l}\text { недосконале навчально-ме- } \\
\text { тодичне забезпечення (під- } \\
\text { ручники, конспекти лекцій, } \\
\text { методичні розробки до усіх } \\
\text { видів робіт та ін.) } \\
\text { недостатнє використання } \\
\text { Інтернет-ресурсів }\end{array}$ & $\begin{array}{l}\text { випуск фахівця, що не від- } \\
\text { повідає вимогам сучасності }\end{array}$ \\
\hline $\begin{array}{l}\text { 1.3. Ризик низької } \\
\text { успішності } \\
\text { студентів }\end{array}$ & $\begin{array}{l}\text { низький рівень попередньої } \\
\text { підготовки } \\
\text { несприйняття матеріалу, що } \\
\text { викладається } \\
\text { неуважність } \\
\text { пропуски занять без поваж- } \\
\text { них причин } \\
\text { невиконання плану СРС }\end{array}$ & $\begin{array}{l}\text { фахівець не набуде загальних } \\
\text { та спеціальних компетентно- } \\
\text { стей у повному обсязі } \\
\text { ускладнюється засвоєння } \\
\text { матеріалу студентом, що мав } \\
\text { перерву у навчанні }\end{array}$ \\
\hline \multicolumn{3}{|c|}{ 2. Ризики матеріально-технічної бази навчання } \\
\hline $\begin{array}{l}\text { 2.1. Ризик } \\
\text { недостатнього } \\
\text { розвитку чи } \\
\text { застарілого } \\
\text { матеріально } \\
\text { технічного } \\
\text { забезпечення }\end{array}$ & $\begin{array}{l}\text { недостатнє фінансове забез- } \\
\text { печення } \\
\text { недостатнє впровадження } \\
\text { інформаційних та інновацій- } \\
\text { них технологій } \\
\text { відсутність обладнання } 3 \\
\text { використанням інформацій- } \\
\text { них технологій } \\
\text { відсутність сучасних лабо- } \\
\text { раторних установок }\end{array}$ & $\begin{array}{l}\text { недоотримання студентами } \\
\text { практичних та теоретичних } \\
\text { навиків роботи }\end{array}$ \\
\hline
\end{tabular}


Продовження таблиці 2

\begin{tabular}{|c|c|c|}
\hline 1 & 2 & 3 \\
\hline \multicolumn{3}{|c|}{ 3. Ризики професорсько викладацького складу } \\
\hline $\begin{array}{l}\text { 3.1. Ризик } \\
\text { некомпетентностей } \\
\text { викладацького } \\
\text { складу }\end{array}$ & $\begin{array}{l}\text { несвоєчасна заміна професор- } \\
\text { сько-викладацького складу } \\
\text { недостатня кількість своє- } \\
\text { часно захищених аспірантів } \\
\text { та докторантів } \\
\text { недостатній досвід роботи } \\
\text { за спеціальністю } \\
\text { низький рівень якості } \\
\text { викладання } \\
\text { вузькопрофільні знання } \\
\end{array}$ & $\begin{array}{l}\text { недоотримання студентами } \\
\text { практичних загальних та } \\
\text { спеціальних компетентно- } \\
\text { стей }\end{array}$ \\
\hline \multicolumn{3}{|c|}{ 4. Ризики наукової діяльності } \\
\hline $\begin{array}{l}\text { 4.1. Ризик низьких } \\
\text { показників наукової } \\
\text { діяльності НПП }\end{array}$ & $\begin{array}{l}\text { низький рівень публікацій } \\
\text { викладачів у наукометрич- } \\
\text { них базах }\end{array}$ & $\begin{array}{l}\text { не буде досягнуто методології } \\
\text { наукових засад та компетент- } \\
\text { ностей необхідних для профе- } \\
\text { сійної діяльності для ефек- } \\
\text { тивного виконання завдань } \\
\text { інноваційного характеру [9] }\end{array}$ \\
\hline $\begin{array}{l}\text { 4.2. Ризик низьких } \\
\text { показників } \\
\text { наукової діяльності } \\
\text { студентів }\end{array}$ & $\begin{array}{l}\text { низький рівень залучення } \\
\text { студентів до наукової } \\
\text { роботи (участь в олімпіа- } \\
\text { дах, конкурсах, виставках, } \\
\text { конференціях, стартапах, } \\
\text { інкубаторах наукових гурт- } \\
\text { ках та ін.) }\end{array}$ & $\begin{array}{l}\text { студенти не досягнуть необ- } \\
\text { хідних наукових навиків } \\
\text { необхідних для здобуття } \\
\text { певного рівня ВО }\end{array}$ \\
\hline \multicolumn{3}{|c|}{ 5. Ризики виховної роботи } \\
\hline $\begin{array}{l}\text { 5.1. Ризики } \\
\text { пов’язані з } \\
\text { організацією та } \\
\text { проведенням занять }\end{array}$ & $\begin{array}{l}\text { некоректний графік } \\
\text { навчального процесу та } \\
\text { розкладу занять } \\
\text { неявка студентів на заняття } \\
\text { (з поважної причини, без } \\
\text { поважної причини) } \\
\text { відсутність викладачів } \\
\text { (через: хворобу, представ- } \\
\text { ництво ЗВО в різних сферах } \\
\text { діяльності (методичні Ради, } \\
\text { Вчені Ради, Спеціалізовані } \\
\text { Ради і т.д.) } \\
\text { відсутність викладачів та } \\
\text { студентів через непередба- } \\
\text { чувану ситуацію }\end{array}$ & $\begin{array}{l}\text { недоотримання студентами } \\
\text { загальних та спеціальних } \\
\text { компетентностей, теоретич- } \\
\text { них та практичних навиків } \\
\text { роботи }\end{array}$ \\
\hline
\end{tabular}


Закінчення таблиці 2

\begin{tabular}{|c|c|c|}
\hline 1 & 2 & 3 \\
\hline $\begin{array}{l}\text { 5.2. Ризик не } \\
\text { проведення } \\
\text { виховної роботи } \\
\text { кураторами- } \\
\text { тьюторами }\end{array}$ & $\begin{array}{l}\text { куратори не виконують } \\
\text { своїх обов'язків (не прово- } \\
\text { дять зустрічей зі студентами } \\
\text { групи та виховної роботи } \\
\text { не приймають участь у різ- } \\
\text { номанітних культурно-масо- } \\
\text { вих заходах } \\
\text { не обговорюють результати } \\
\text { навчання і т.д.) }\end{array}$ & $\begin{array}{l}\text { не виконання НПП виховної } \\
\text { роботи навчального процесу } \\
\text { студенти не володітимуть } \\
\text { необхідною інформацією } \\
\text { незадоволеність студентами } \\
\text { умовами навчання та про- } \\
\text { живання в гуртожитку }\end{array}$ \\
\hline \multicolumn{3}{|c|}{ 6. Ризики випуску фахівців } \\
\hline $\begin{array}{l}\text { 6.1. Ризик } \\
\text { невидачі диплому } \\
\text { відповідного рівня } \\
\text { ВО }\end{array}$ & $\begin{array}{l}\text { студента було відраховано: } \\
\text { за неуспішність } \\
\text { за порушення графіку відві- } \\
\text { дувань занять } \\
\text { за не оплату навчання } \\
\text { (контрактна форма навчання) }\end{array}$ & $\begin{array}{l}\text { впливає на престижність } \\
\text { ЗВО } \\
\text { втрата контингенту }\end{array}$ \\
\hline $\begin{array}{l}\text { 6.2. Ризик } \\
\text { невчасної видачі } \\
\text { диплому про ВО }\end{array}$ & $\begin{array}{l}\text { затримка видачі диплому } \\
\text { в зв’язку з виготовленням } \\
\text { диплому за певних обставин } \\
\text { студента (несплата за диплом } \\
\text { не підписаний обхідний лист, } \\
\text { сімейні обставини, декретна } \\
\text { відпустка, хвороба та ін.) }\end{array}$ & $\begin{array}{l}\text { виникають проблеми з пра- } \\
\text { цевлаштуванням } 3 \text { причин } \\
\text { затримки видачі диплому }\end{array}$ \\
\hline $\begin{array}{l}\text { 6.3. Ризик випуску } \\
\text { некомпетентного } \\
\text { фахівця }\end{array}$ & $\begin{array}{l}\text { випускник (відповідного } \\
\text { рівня вищої освіти) не досяг } \\
\text { необхідних результатів } \\
\text { навчання (отримав низький } \\
\text { рівень знань) та недостатній } \\
\text { рівень практичних навиків }\end{array}$ & $\begin{array}{l}\text { роботодавці отримають } \\
\text { некомпетентного фахівця, } \\
\text { який не відповідає ква- } \\
\text { ліфікаційному рівню, що } \\
\text { матиме негативний вплив на } \\
\text { престиж 3ВО } \\
\text { втрата контингенту } \\
\text { недоотримання роботодав- } \\
\text { цями необхідних спеціалістів }\end{array}$ \\
\hline
\end{tabular}

На нашу думку, аналіз ризиків буде ефективним у випадку застосування напівкількісного ранжування ризиків експертною групою.

Найбільш розповсюдженими методами кількісного оцінювання $\epsilon$ «Матриця наслідків/ймовірностей» та «Картографування ризиків». Суть методу - «Матриця наслідків/ймовірностей» полягає у поєднанні якісних та напівкількісних оцінок ймовірностей та наслідків що дозво- 
ляє проранжувати ризики та визначити їх рівень. Даний метод, як правило застосовується для визначення пріоритетності аналізу ризиків [3].

Метод базується на використанні спеціальних шкал, вибір яких обумовлюється діапазоном ймовірності та наслідків, які об'єднуються матрицею. При цьому найнижча ймовірність характеризує найбільш небезпечний ризик.

До переваг даного методу слід віднести простоту застосування, а до недоліків труднощі однозначного визначення шкал для рівнів ризиків для різних категорій наслідків.

Практичний досвід доводить, що універсальним інструментом ризик-менеджменту є «Карта ризиків». Згідно [10] вона будується на основі остаточно сформованого переліку (реєстру) ризиків, їх якісному та кількісному оцінюванні. На рис. 4 наведена карта ризиків освітнього процесу КНУТД.

Як видно 3 рис. 4, найбільший вплив на освітній процес має - ризик невідповідності освітньої програми 1.1 (таблиця 2). Даний ризик попадає у «дуже високу» зону впливу та ймовірності. В зону «високого» впливу потрапляє - ризик випуску некомпетентного фахівця - 6.3 (таблиця 2). Зона високого впливу та середньої ймовірності має високий рівень впливу. Наведені вище ризики, що попадають в зону впливу та ймовірності «високий - дуже високий» потребують особливої уваги з боку керівництва ЗВО та розроблення і впровадження комплексу дій щодо їх зменшення, оскільки вони вийшли за межі критичної границі (жирну криву лінію). Ризик недостатнього розвитку чи застарілого матеріально-технічного забезпечення 2.1 (таблиця 2) знаходиться на межі критичної зони терпимості ризиків. Слід зазначити, що ці ризики, в будь-який момент можуть потрапити у «високу зону», тому вони також потребують прийняття рішень щодо їх зменшення. Ризики, які потрапляють в зону середньої вагомості, потребують періодичного контролю, з метою мінімізації їх впливу на освітній процес. Ризики, які знаходяться в зоні «значний - незначний» не мають особливого впливу на освітній процес, тому як правило не несуть загрозу якості його проведення й потребують меншої уваги.

Таким чином, результати застосування методу картографування дозволяють ранжувати ризики за вагомістю, тобто оптимізувати їх перелік для подальшого аналізу оцінювання наслідків впливу. Це дає можливість ЗВО визначити найбільш схильні до ризику зони освіт- 


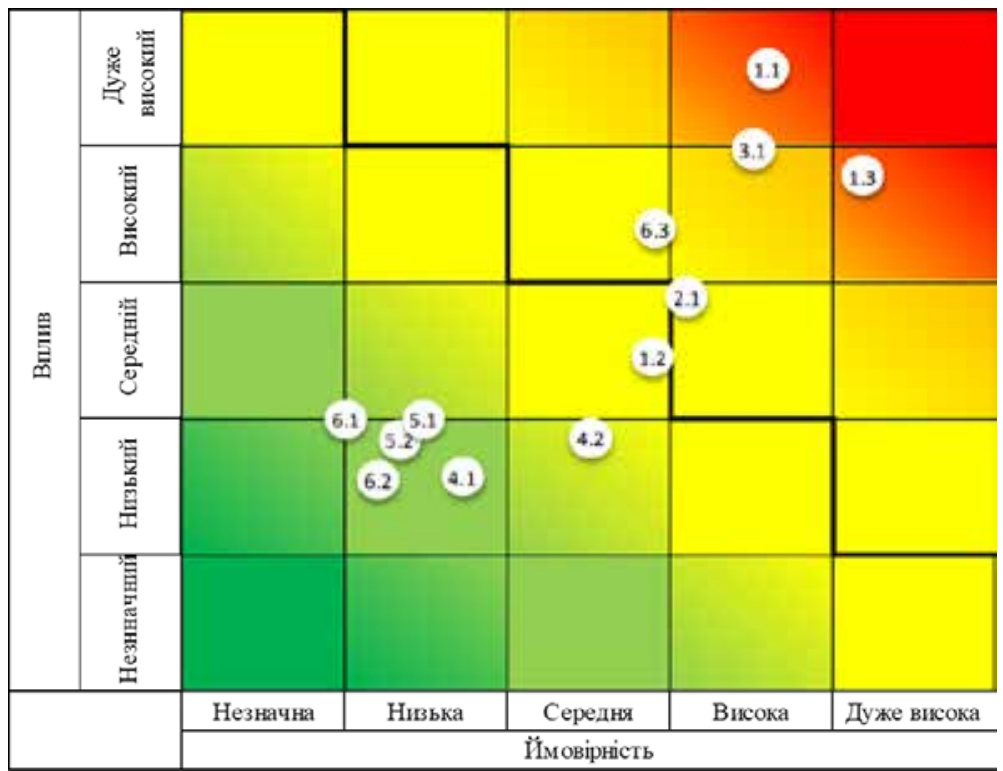

Рис. 4. Карта ризиків освітнього процесу

нього процесу та передбачати в майбутньому розробку дієвих способів контролю та механізмів їх мінімізації.

Наступним підетапом загального оцінювання ризиків є перевірка результатів на вірогідність інформації - 3.4, у разі, якщо інформація не достовірна то перехід відбувається на підетап - 3.2. У разі, якщо якісного аналізу недостатньо, потрібно повернутись на підетап 3.1, у випадку, якщо інформація достовірна то переходимо на підетап - 4 .

До підетапу 4, входять наступні процедури: розроблення (погодження та впровадження) плану дій.

Наприклад, план дій повинен включати: посилення контролю, шляхом введення додаткових перевірок розроблених чи існуючих освітніх програм на відповідність до вимог чинної нормативної бази; моніторинг навчально-методичного забезпечення; проведення додаткових зрізів знань студентів; залучення спонсорів, меценатів для закупівлі нового сучасного обладнання; проведення планового підвищення рівня кваліфікації науково-педагогічних працівників, проведення тематичних заходів, щодо 
обміну досвіду між НПП, різних напрямів викладання; посилення контролю наукової діяльності НПП і студентів; заохочення студентів до наукової діяльності; введення реєстру відвідувань студентами та НПП занять; контроль за проведенням виховної роботи кураторами-тьютерами; друкувати дипломи у перевірених типографіях; проводити моніторинг набутих студентами компетентностей, відповідно до освітньої програми тощо.

Алгоритм оцінювання ризиків освітнього процесу ЗВО, який наведено на рис. 1 має замкнутий цикл і згідно з принципами TQM спрямований на постійне поліпшення, шляхом моніторингу і перевірки достовірності інформації. Моніторинг є невід'ємною процедурою процесу управління ризиками та дає можливість проводити критичний аналіз обробки ризиків та перевіряти дієвість заходів щодо їх мінімізації. Запланований за даним алгоритмом моніторинг, доцільно проводити за схемою наведеною на рис. 5.

За результатами моніторингу робочою групою розробляються i впроваджуються коригуючі і попереджуючі дії, які дозволяють знизити ризики освітнього процесу.

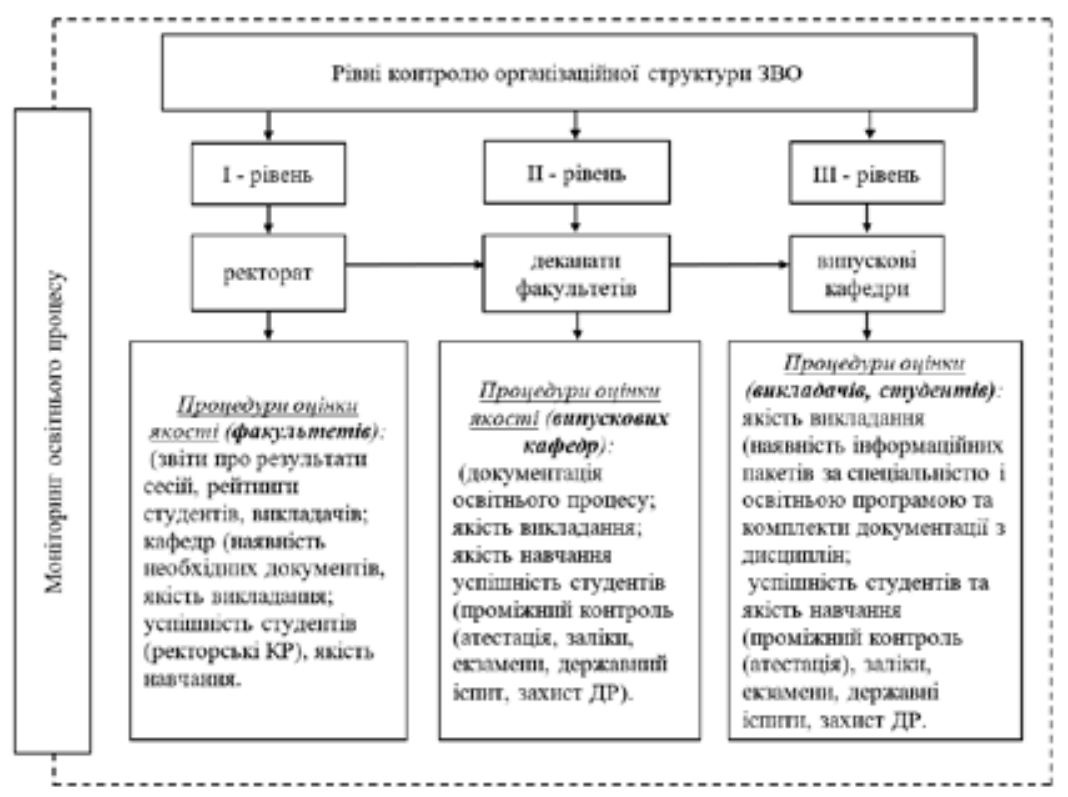

Рис. 5. Схема моніторингу освітнього процесу 3 ВО 


\section{3. Висновки}

Результати досліджень доводять доцільність застосування вимог стандарту ДСТУ ISO 31010:2013 для ідентифікації та аналізу потенційних ризиків освітнього процесу ЗВО. Для оцінювання ризиків освітнього процесу розроблено спеціальний чотирьох кроковий алгоритм, в основу якого покладено системний підхід, принципи загального управління якістю (TQM), ризик-менеджмент та вимоги стандарту ДСТУ ISO 31010:2013. Застосування даного алгоритму дозволяє оцінювати ризики освітнього процесу на всіх етапах його життєвого циклу та за результатами моніторингу розробляти організаційно-технічні заходи по їх зменшенню.

Для практичної реалізації алгоритму розроблені методичні рекомендації, які стосуються загального оцінювання ризиків (ідентифікації, якісного аналізу та кількісного оцінювання).

Перспективи подальших досліджень, на наш, погляд пов'язані 3 більш детальним вивченням ризиків освітнього процесу, зокрема їх впливом на економічні складові діяльності закладів вищої освіти.

\section{Список літератури:}

1. ISO Guide ISO 73:2009 «Risk management - Vocabulary - Guidelines for use in standards».

2. ISO 31000:2018 «Risk management - Guidelines».

3. ДСТУ ISO 31010:2013 (IEC/ISO 31010:2009, IDT) «Керування ризиком. Методи загального оцінювання ризику». - Київ : Мінекономрозвитку України, 2015.

4. Волівач А.П. Застосування SWOT-аналізу для оцінювання ризиків діяльності ЗВО // А.П. Волівач, Г.І. Хімічева // Вісник інженерної академії України. - 2018. - № 4. - С. 196-203.

5. Волівач А.П. Класифікація ризиків навчального процесу на основі застосування методу ієрархій // А.П. Волівач, Г.І. Хімічева // Monografia Pokonfenrencyjna. Science, Research, Development. №19 (Наука, исследования, развитие. №19) 30.07.2019 - 31.07.2019 Valletta (Republic of Malta). C. 96-106.

6. Волівач А.П. Застосування методу PEST-аналізу для визначення впливу факторів ризиків на освітню діяльність ЗВО / А.П. Волівач, Г.І. Хімічева // Проблеми інженерно-педагогічної освіти. Збірник наукових праць. - 2018. - Випуск 59. - С. 74-82. - Режим доступу: https://er.knutd.edu.ua/ bitstream/123456789/12478/1/20190516_302.pdf (дата звернення: 27.10.2019).

7. Волівач А.П. Звіт за ініціативною темою № 0116U008731 «Оцінювання ризиків освітніх послуг відповідно до вимог стандартів і рекомендацій ESG та міжнародних стандартів ISO 9001:2015» / А.П. Волівач, Г.І. Хімічева // м. Київ, КНУТД, 2018. - 84 с.

8. Волівач А.П. Визначення факторів ризиків у відповідності до моделі СУЯ ВНЗ за вимогами ДСТУ ISO 9001:2015 / А.П. Волівач, Г.І. Хімічева // 
Міжнар. конф. «Інноваційні технології в науці та освіті. Європейський досвід» ТОМ І. 21 листопада - 24 листопада 2017 р., м. Відень, Австрія. С. 48-57.

9. Закон України «Про вищу освіту» Документ 1556-VII, чинний, поточна редакція - Редакція від 09.08.2019, підстава - 2745-VIII. - Режим доступу: https://zakon.rada.gov.ua/laws/show/1556-18 (дата звернення: 27.10.2019).

10. Пименов Н.А. Управление финансовыми рисками в системе экономической безопасности : учебник и практикум / Н.А. Пименов, В.И. Авдийский ; под общей редакцией В.И. Авдийского. - Москва : Издательство Юрайт, 2016. 413 с. - (Бакалавр. Академический курс). - ISBN 978-5-9916-3110-5.

\section{References:}

1. ISO Guide ISO 73:2009 «Risk management - Vocabulary».

2. ISO 31000:2018 «Risk management - Guidelines».

3. DSTU ISO 31010:2013 (IEC/ISO 31010:2009, IDT) «Keruvannia ryzykom. Metody zahalnoho otsiniuvannia ryzyku». - Kyiv: Minekonomrozvytku Ukrainy, 2015. (in Ukrainian)

4. Volivach A.P., Khimicheva H.I. (2018). Zastosuvannia SWOT-analizu dlia otsiniuvannia ryzykiv diialnosti ZVO. Visnyk inzhenernoi akademii Ukrainy, 4, 196-203. (in Ukrainian)

5. Volivach A.P. Klasyfikacija ryzykiv navchaljnogho procesu na osnovi zastosuvannja metodu ijerarkhij // A.P. Volivach, Gh.I. Khimicheva // Monografia Pokonfenrencyjna. Science, Research, Development. № 19 (Nauka, yssledovanyja, RAZVYTYE. №19) 30.07.2019 - 31.07.2019 Valletta (Republic of Malta).

6. Volivach A.P., Ximicheva G.I. (2018). Zastosuvannya metodu PEST-analizu dlya viznachennya vplivu faktoriv rizikiv na osvitnyu diyalnist ZVO. Problemi inzhenerno-pedagogichnö̈ osviti. Zbirnik naukovix pracz, 59, 74-82.

7. Volivach A.P. (2018). Zvit za iniciatyvnoju temoju №0116U008731 «Ocinjuvannja ryzykiv osvitnikh poslugh vidpovidno do vymogh standartiv i rekomendacij ESG ta mizhnarodnykh standartiv ISO 9001:2015» / A.P. Volivach, Gh.I. Khimicheva. - Kyiv: KNUTD. (in Ukrainian)

8. Volivach A.P. (2017). Vyznachennja faktoriv ryzykiv u vidpovidnosti do modeli SUJa VNZ za vymoghamy DSTU ISO 9001:2015 / A.P. Volivach, Gh.I. Khimicheva // Mizhnar. konf. «Innovacijni tekhnologhiji v nauci ta osviti. Jevropejsjkyj dosvid» T. I. 21 lystopada - 24 lystopada 2017 r., Videnj, Avstrija.

9. Zakon Ukrainy «Pro vyshchu osvitu» [Law of Ukraine «Higher Education»]. (n.d). Retrieved from: http://zakon4.rada.gov.ua/laws/show/1556-18/ (in Ukrainian)

10. Pymenov N.A. (2016). Upravlenye fynansovыmy ryskamy v systeme ekonomycheskoj bezopasnosty : uchebnyk y praktykum / N.A. Pymenov, V.Y. Avdyjskyj; pod obshhej redakcyej V.Y. Avdyjskogho. - Moskva : Yzdateljstvo Jurajt. (Bakalavr. Akademycheskyj kurs). - ISBN 978-5-9916-3110-5. 